\title{
Architecture, that wins peaks - triumph or confusion
}

\author{
Anna Wojtas Harań ${ }^{1, *}$ \\ ${ }^{1}$ Departament of Architecture, Housing, Industrial, Interior, Rural Planning, Landscape, Visual Arts, \\ Faculty of Architecture, Wrocław University of Science and Technology, Poland
}

\begin{abstract}
The natural landscape provokes artists to revive it with architecture. Architects overcome technical limitations, physiographic, customary more or less picturesquely incorporating their works into the richness of natural forms. Many benefits come from this recklessness for the region. The hit trend is also appreciated for the triumph of technical thought. It puts into confusion at once because of the gradual takeover of the natural environment. The aim of the work is to search for solutions that would help preserve the beauty of the mountain environment and at the same time make the widest group of recipients available. Analyzing the above issues, the comparative method was used, presenting achievements in the field of high-altitude objects design in extreme physiographic conditions, implemented in the Alps region. The region has a developed ski and tourist infrastructure. It is an example of maintaining moderation and specific character, despite growing new needs and expectations from tourists and sportsmen. However, it is not free from the over-investment trap.
\end{abstract}

\section{Preface}

Clean glaciers, lakes, quiet valleys, deep ravines, animals leaving the hiding place in search of food, human footprints only on hiking trails, peaceful villages. More than a century ago amateurs of such mountains are now looking for contact with nature in romantic huts in a remote area. Modernized shepherd's huts are popular among tourists as hotels. Some, from the times when shepherds were in them. Particular contact with nature can be found in isolated shelters. However, there are few places for lovers of the unspoilt mountain scenery. In order to effectively separate yourself from the world of urban civilization, you have to climb higher and higher, reaching the highest mountain parties. But even there, along with modern investments, there are many tourists who are not absolutely interested in unpolluted view of the mountains, followed by further investments.

What astonishment comes to those who decide to reach the tops of Europe with the expectation of a unique contact with the nature of the mountains. They often find the remains of the glacier covered with a plastic tarpaulin. In the mass of the chattering crowd, arriving in cable cars and gondolas, professionally equipped mountaineers look amazing today .

\footnotetext{
* Corresponding author: anna.wojtas-haran@pwr.edu.pl
} 
The landscape of the Alps under the pressure of tourism and the absurdities of modern times is shown by photographer Lois Hechenblaikner in the publication Winter Wonderland. The writer Bernhard Kathan (adding the text to photographies) perceives alpine investments, such as: roads, artificial excavations, embankments, without which mass tourism could not exist, as deep wounds, given the nature of the mountains. He says that huge areas of the Alps are becoming industrial zones with largely artificial skiing routes, countless lifts and gloomy conglomerates of hotels. Sociologist Gerhard Schulze exposes the tendencies and behaviors observed in mountain areas, partly depicted in Hechenblaikner's photographs. To appear, to experience, to go wild, to pass, to achieve more, to have more - these are attitudes that in turn translate into instrumental thinking about the development of mountains - this thinking „eats its way into mountainsides" [1], ,flattening slops when they obstruct progress or even creating new mountains if need be" [2].

Thanks to the growing possibilities, genius of engineers, the mountains can now offer everyone a set of emotional experiences. Attractions start in the valley and end on the glacier

Mayrhofen is the informal capital of the extensive and densely built-up the Zillertal (Ziller river valley). In the town, apart from all the attractions of après-ski, there are more accomodations than in Salzburg. From there, the roads to high-altitude mountain valleys start. One of them leads to the most popular Austrian glacier - the Hintertux Glacier. The king of glaciers is open to skiers throughout the year.

Interest in glaciers increases due to uncertainty and deficit of snow. The winter season in Austria begins on the Rettenbach Glacier. Similarly, on glaciers: Kaunertal, Pitztal, Sölden-Ötztal, Stubai, Dachstein, at altitudes close to 3000 m.a.s.l., downhill and crosscountry trails are located, as well as other attractions.

Railways, cableways, cog railways, gondolas, lifts connect valleys with glaciers into one "wonderland". The traction network is constantly replenished. In Austria, in 2016, the newest realizations were created: Giggijochbahn - gondola to the Rettenbach Glacier and 3s Eisgratbahn - chairlift to the Stubai Glacier. In Italy, in 2015, Skyway Monte Bianco was opened - the cable car to Punta Helbronner in the Mont Blanc Massif, to one of the highest places in Europe, and available to an ordinary mortal - not necessarily a walker or climber.

Ski areas and mountain parks of tourism, leisure and play, communicated with the pioneer engineering solutions mentioned here, became the habitat. Accumulation of attractions in one place often makes contact with the nature of mountains, almost secondary. For example, the perfectly organized Ski Welt Wilder Kaiser, on the western edge of the Kitzbuhel Alps, is one of the largest ski areas in Austria and considered the best in the Alpine ski arena ${ }^{2}$.

Mountain peaks and glaciers, steep walls are lined with impressive high-altitude roads, accessible for wheel traffic. A thick crowd fascinated by the sights gets to the tops, straining the car engines and brakes. Roads, often leading through protected areas, are a tourist business, a commercial success, and another symptom of changes that mountains are subjected to. To the Pasterze Glacier, at the foot of the eastern walls of Grossglockner, in the Eastern Alps, runs the Alpine road Grossglockner - Grossglockner Hochalpenstrasse [3]. $8-9$ million visitors annually reach the place to watch this spectacle, closely related to the natural and cultural environment. Streamers and picturesque roads lead: to the Timmelsjoch Pass (on the border of the Ötztal and Stubai Alps), to the Arlberg Pass and to the Flexen Pass (in the Lechtal Alps), to the foot of Styria's highest mountain Hoeher Dachstein (Dachsteinstrasse) or to Gerlos Pass in the Nationalpark Hohe Tauerrn (Gerlos Alpenstraße). All these intriguing solutions are accompanied by spectacular construction

${ }^{2}$ There are: $284 \mathrm{~km}$ of ski slopes, 4 snowboard parks, 3 sledging routs, slalom tracks, illuminated ski slopes, over 80 restaurants and huts, over 90 lifts, 1700 cannons (covering $229 \mathrm{~km}$ of routes in 3 days with drinking water quality and energy-driven from renewable sources), the igloo village - AlpenigluDorf i Hochbrixen at the altitude of 1676 m.a.s.l. (among others: ice bar, ice chapel, hotel, exhibition of ice sculpture). 
objects, erected in extreme locations, often in the highest parts, where there is a zone of eternal snow. Depending on the slope exposure, the permanent ice cover is above the level (e.g. in the Alps) between 2500 m.a.s.l and 3200 m.a.s.l. The rules of wind, sun and snow govern these altitudes. In an unfriendly environment, the following issues must be considered:

- physiographic (low temperature and lower oxygen content in the atmosphere, powerful wind force, complicated topography, soil instability),

- assembly and transport (extremely arduous conditions for conducting construction works, limitations in access to the construction site),

- exploitation (energy supply and disposal of sewage and waste),

- environmental protection (application of ecological solutions),

- aesthetics (choice between traditional architecture and modern, often shocking structures).

Here are examples of the latest, significant realizations of recent times.

\section{Alpine realizations}

The new Gervasutti shelter [4].

The new Gervasutti shelter (fig. 1) is located in the Mont Blanc Massif, on a rock wall above the Frébouga Glacier. Built at an altitude of 2833 m.a.s.l., it is a haven for hikers and a starting point for climbing the Grandes Jorasses. The author of the project is the Italian company LEAPfactory, which specializes in construction in extreme conditions and at the same time with a minimal impact on the environment. The acronym in the name means living, ecological, alpine pod. The shelter was installed in November 2011. The outer shell as well as interior furnishings consists of light prefabricated elements. The modular structure facilitates installation in a demanding location and creates a chance for possible future expansion or replacement of worn-out parts. The elements were delivered to the site by helicopter and assembled, in a short time - 2 days. In contrast to the futuristic facade, the interior is traditionally wood finished. The structure is equipped with the following technologically advanced equipment: an integrated station for monitoring and reading information on the prevailing conditions inside and outside the building, photovoltaic panels in the outer shell providing electricity. The signaling, red color is important for orientation. While, the pattern used, inspired by the stitch of mountain sweaters, is designed to create a feeling of warmth and comfort. Arrangement of the rear part of the sleeping capsule resembles the compact interior of the rail wagon. It is filled with bunk beds and storage compartments. The living area, which has a kitchen and a dining room, is lit by a large panoramic window overlooking the valley. The project refers to architectural ideas of the Archigram architects group, from the 1960s. Concepts of miniature capsules, or mobile residential platforms, carried by cranes and incorporated in any space into a spatial structure, fit the contemporary then visions of the urban future. Self-sufficient capsules, to survive in unfriendly situations, have become an inspiration for people aspiring to a non-traditional lifestyle. 


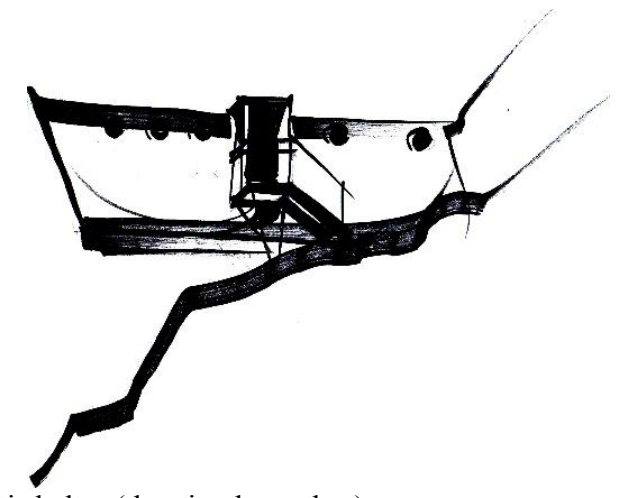

Fig. 1. The new Gervasutti shelter (drawing by author).

The new cableway Skyway Monte Bianco [5].

Skyway Monte Bianco exports from the Aosta Valley to 3500 m.a.s.l., anyone who wants to approach Mont Blanc and majestic glaciers. The Skyway Monte Bianco railway runs between 3 stations: Courmayeur - Pontal d'Entrèves (fig. 2) at 1300 m.a.s.l., Pavillon du Mont Fréty (fig. 3) - at an altitude of 2200 m.a.s.1., Punta Hellbronner (fig.4) at an altitude of approximately 3464 m.a.s.l. The stations houses multifunctional spaces such as: observation terraces, exhibitions, bars, restaurants, botanic garden, cellar (where the production of wines with specific characteristics resulting from height and temperature takes place), conference room, retail space, children's playground, nature paths and a glassed viewpoint over the glacier.

The complex of three stations is not uniform, but adapted, according to Studio Progetti designers, to scenery at various heights. The Pontal d'Entreves building has aerodynamic shapes. The sinusoidal curve of the roof blends seamlessly into the landscape. The ribbed structure rises towards the mountains, following the cable car path. From the west it descends low to the ground, protecting itself against the influence of wind. The wavy roof is supported by small steel truss arches based on four-arm supports.

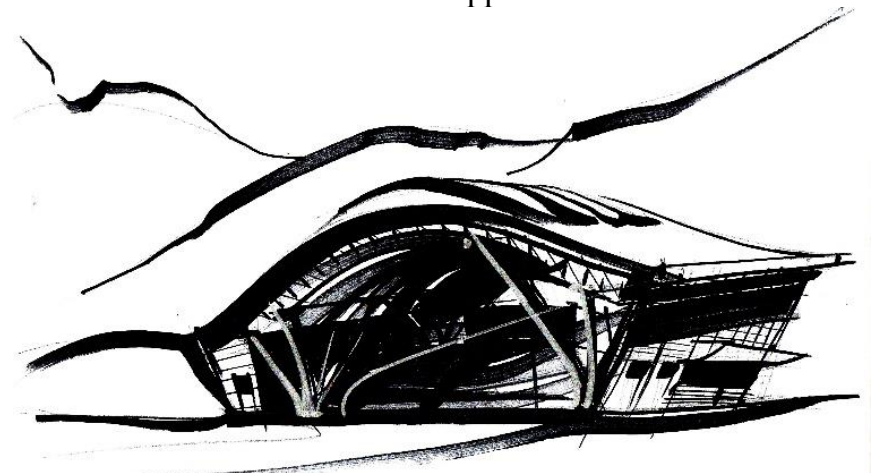

Fig. 2. Pontal d'Entrèves (drawing by author).

Pavillon du Mont Frety consists of two opposing arched roofs, in the shape of opposite slopes of the valley. The angle of inclination of the structure results from the cable car profile. The bending of the cover of the departure platform reveals a grid of horseshoe-shaped steel support ribs and a view of the machinery. The glass elevation of the lower storey, on the plan of the wheel section, offers a panoramic view of valleys. 


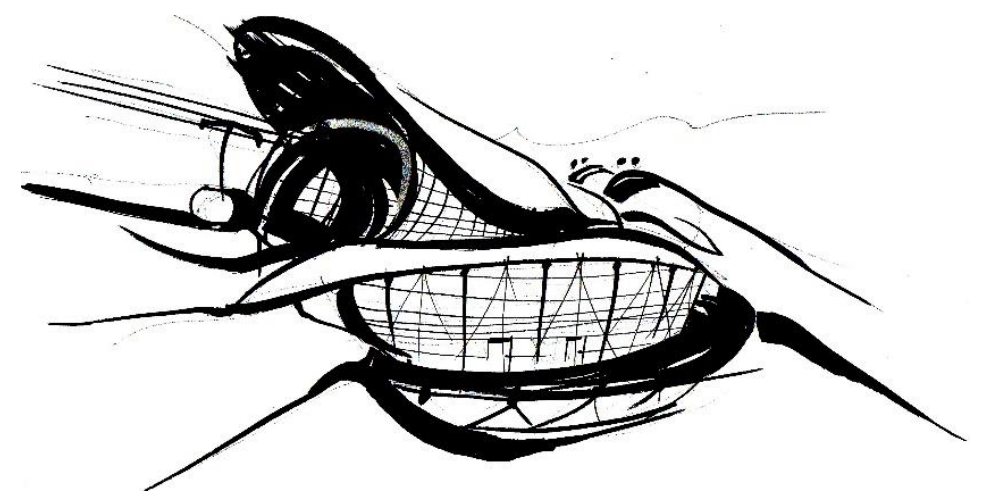

Fig. 3. Pavillon du Mont Fréty (drawing by author).

Punta Helbronner rests on a rocky summit of the same name. The rock penetrates into the architectural structure, becoming an element of interior decoration of the restaurant. Due to the small area, the building was vertically piled up using cantilever terraces. According to the authors, the project recreates a harsh, rocky environment. The form of the building imitates quartz crystals dispersed in various directions. The angular structures are made of materials resistant to atmospheric factors, unfavorable for the accumulation of snow and ice on its surfaces. The ground floor is made of reinforced concrete. The upper part and the outer façade is made of zinc titanium coated steel. Triple glazing provides optimal thermal conditions and at the same time a natural insight into space. Glass panels were transported upwards using a pulley system in the warm months of the year.

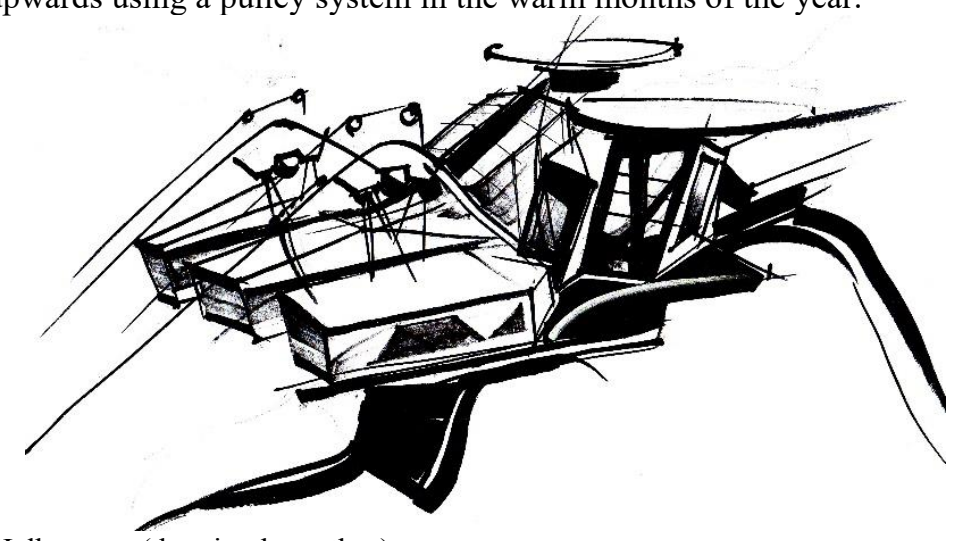

Fig. 4. Punta Helbronner (drawing by author).

From the upper station it is easy to reach by a tunnel and a system of cages and lifts to the Rifugio Torino shelter, which is a resting place for mountaineers. In the opinion of many, here only in the old hostel, with traditional, modest architecture from 1952, you can feel the real atmosphere of being in the aura of the highest mountain of Europe. The building is located on a rocky ledge at an altitude of 3375 m.a.s.l.

\section{Tourist complex on Klein Matterhorn}

The highest located in Europe: restaurant, railway station, as well as a cinema, ice cave, ski resort open all year ${ }^{3}$ are located on Klein Matterhorn - Matterhorn Glacier Paradise. Built here in 2008 (according to the project of the Peak Architekten office) [6], the restaurant (fig. 5) is attached to the rocks emerging from the glacier. Lapidariness of the block and

\footnotetext{
3 The largest summer area in the world with 21 kilometers of prepared ski routes.
} 
colors, imitating stone floor, inscribes the building into a glaciated mountain landscape. The designers' aspirations were the optimal use of solar energy, protection against wind and snowdrifts, and their own water treatment system. For reasons of economy, the basement was made in massive technology, and floors made of prefabricated wooden elements. A two-layer façade consisting of an internal wooden and external metal integrated with solar panels was used. The space between them is filled with air, which is used to heat the building. The double façade protects the solar panels from overheating, increasing their efficiency. Excess energy is used to operate the cable car connected to the restaurant by a mountain tunnel.

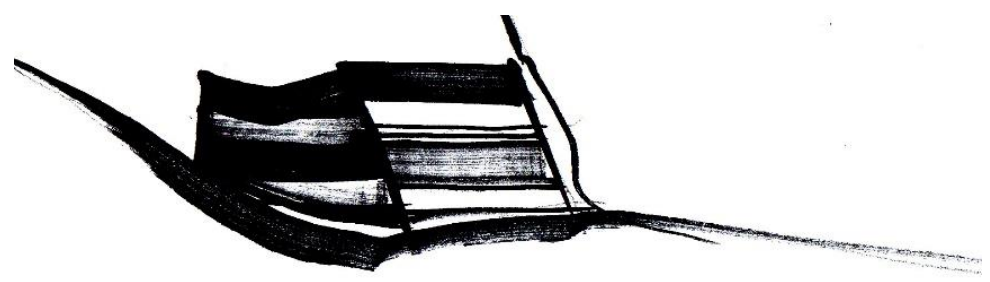

Fig. 5. Restaurant - complex on Klein Matterhorn (drawing by author).

The upper cableway station, as well as the restaurant, is located at an altitude of 3820 m.a.s.l. The reinforced concrete, geometric design of the terminal (fig. 6) is ruthlessly stuck to the summit from the north. The construction of the railway started in 1976 and required atypical solutions, such as transporting concrete in specially insulated tanks mixed with warm water and antifreeze.

Currently, the construction of a new cable car - the world's highest 3s cableway [7] with the buildings of two stations. The facade of the lower station will be largely glazed to ensure direct contact with the surroundings. The upper station (fig. 6) is planned at an altitude of 3821 m.a.s.l. According to the vision of the designers, it will contrast with the reinforced concrete "fortress" of the old cableway, lightness of the structure. The creation of steel and glass will grow on the western side of the summit. It will remain in the style of mountain crystals. A mountain of refined shape will be ripped open by another tunnel and the new investment will squeeze its controversial mark.

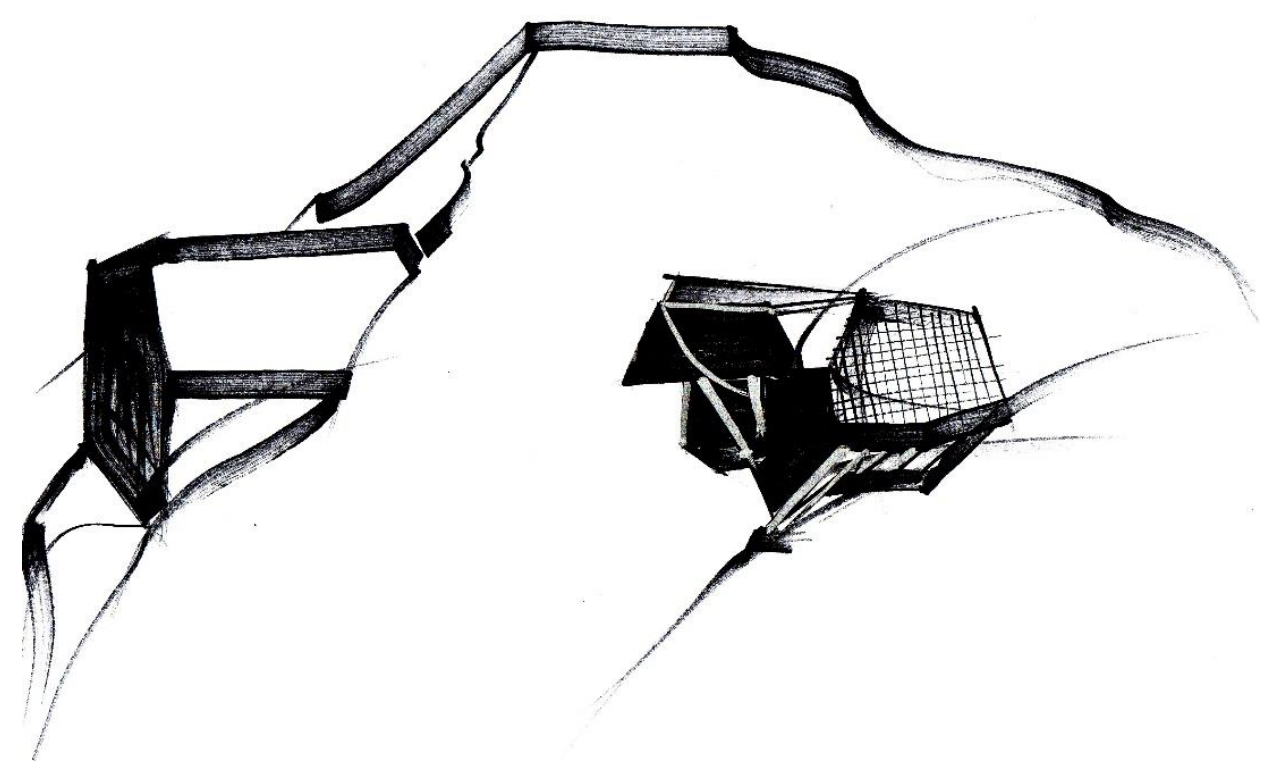

Fig. 6. Old and new cableway stations - complex on Klein Matterhorn (drawing by author). 
Cable car stations at Chässerugg [8].

On the top of Chässerugg mountain, at an altitude of 2260 m.a.s.l., in the Toggenburg region in Switzerland, architects from the Herzog \& de Meuron office designed the cable car stations with the restaurant (fig. 7). The idea of the project differs from the popular imitations of huts or the aforementioned spectacular structures. The project aims to refer to the Alpine heritage, but avoid pastiche. "We tried to create a language that suits Toggenburg, without falling into the trap of popular alpine stereotypes" [9] - explains architect Christine Binswanger. In this way, the original object was created, inspired by the shape of a huge barn, nevertheless more sophisticated. Asymmetrically spread roof, emphasizing the outline of the rock face, exposed branched supports, slanted chimney line, a distinctive strip of glazed façade, terrace anchored above the precipice, blend in with the landscape, spared so far by modern construction achievements. In 2015, the wooden structure absorbed the old cable car, created in 1970. Locally obtained spruce wood was used for the construction. Local craftsmen were hired. All prefabricated elements were brought by train, with the exception of the lift, which was transported by helicopter. Components made of solid wood were put on top during the summer and lay on a reinforced concrete foundation. Most of the EspelStöfeli gondola lift - Chäserrugg have a uniform architectural design, simple, based on native, rural construction techniques. Everywhere the same materials and limited amount of colors and attention to detail were used. Even installations have a non-accidental color. This place is different from other tourist resorts. It was also created for those who are looking for peace, slowing down, but not skipping hurried skiers and groups of short-term tourists.

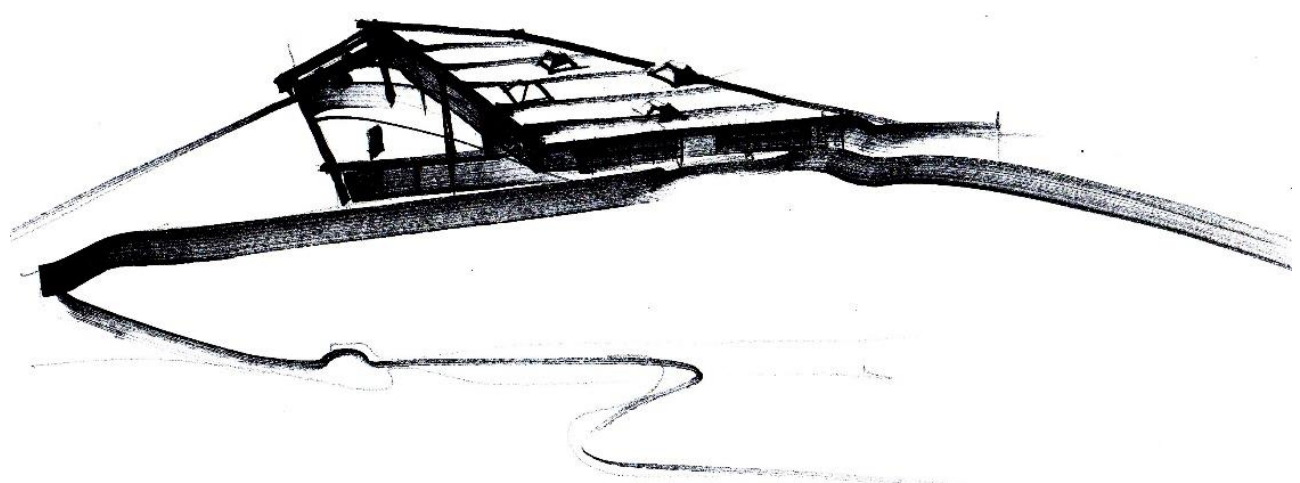

Fig. 7. Cable car stations at Chässerug (drawing by author).

Viewing platforms [10].

When the repertoire of cubature proposals is already exhausting, you can always mount a viewing platform with shocking shapes and come into being in a free space. Platforms provide a special experience in discovering the landscape. They allow you to reach effective "shots". The other ones are worth paying attention to themselves.

The 5 fingers (fig. 8a) lookout platform was created 2006 on the mountain slope of Hohe Krippenstein (2108 m.a.s.1.) in the Dachstein Massif. Openwork, steel, hand-shaped structure towers $400 \mathrm{~m}$ above the abyss. From overhanging branches of the platform, at about $4 \mathrm{~m}$ from the vertical edge, and through intentionally designed openings on the platform, the vast abyss is visible and a view of the Hallstattersee lake and the Salzkammergut region.

Nearby, on a wide flattening, the Welterbespirale platform (fig. 8b) was mounted in the shape of an aluminum ship - a spiral. This is another attraction, competitive to explore the calcareous nature of the rocky massif. 
On the opposite side of the Dachstein Massif, on the southern slopes of Hoher Dachstein (2995 m.a.s.l.), above the rock rift, a hanging bridge "stairs to nothingness" and a glass platform hung in 2017 (fig. 8c). Being on openwork, seemingly rickety, steel constructions, which wraps the crags, strengthens the impression of floating over 400 meters of space.

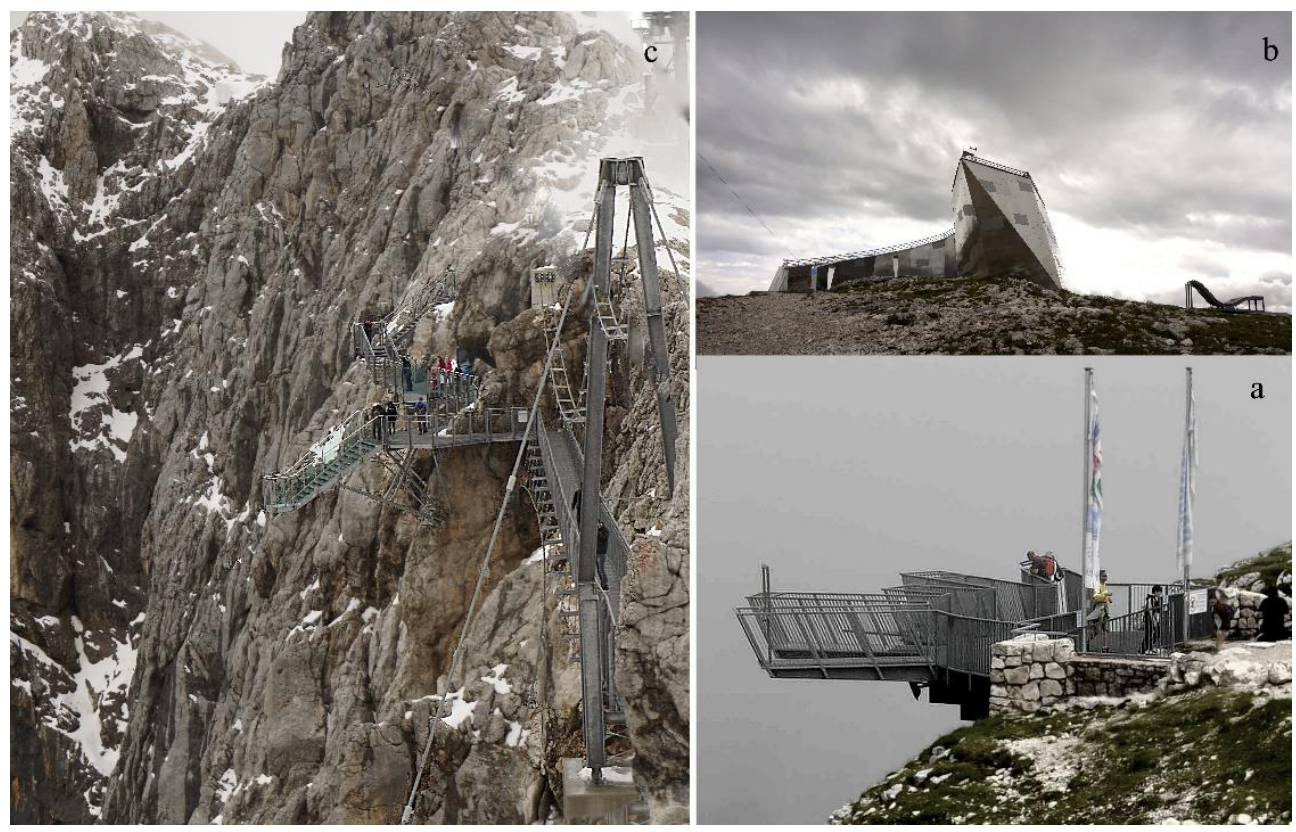

Fig. 8 . a) 5 fingers platform b) Welterbespirale platform c) "Stairs to nothingness" - bridge and glass platform (photos by author).

\section{Summary}

The alpine landscape is fascinating with impeccability and unavailability. Delight and adversity have made the mountains a challenge not only for wanderers, but also for architects. Many of the most beautiful locations have transformed into architectural experiments. Initially, local buildings and later buildings using traditional patterns, associated with a sense of warmth and security, gave shelter to travelers [11]. Already in 1930s, concepts emerged using prefabricated lightweight structures and aluminum components, easy to transport and assemble, and at the same time resistant to weather conditions. Experiments were carried out with a minimum usable space and mobile interior furnishings (e.g. building named refuge bivouac showed at the Paris international exhibition in 1937 and next refuge tonneau designed in 1938). Such solutions are still used and improved. At the same time, installation equipment, technology and advanced construction are demonstrated. There is diversity in the choice of style: cosmic metaphors, conventional motifs, minimalist right angles, expressive bevels, stiff geometry, gentle curves, mobile capsules, timeless monoliths. The tendency to expose the work is visible, at the cost of even distortion of the topography of the area. Compilation of opposing conventions and values can transform into chaos encountered in commercial, suburban commercial or industrial districts.

Until now, the mountains have fascinated not only with noble nature, but also with a sophisticated, peculiar architecture. The natural conditions blocked excessive and accidental development. On the background, often fictitious author's narratives, about the efforts to enter the object into the context, the restaurant on Chässerugg, deserves 
attention. Their designers make an authentic attempt to establish relations with native architecture.

The examples of architecture in extreme conditions, presented here, make up the syndrome of our time - a potentially new anthropocene epoch. Its beginning was adopted in the middle of the 20th century. It is distinguished by a "thick layer of concrete". "As many as $98 \%$ of the 500 billion tons of concrete that we poured out into the Earth in the entire history of mankind, we used to build houses, roads or bridges in the last 70 years. For every square meter of the Earth's surface, including the ocean, there is a kilogram of concrete today"[12].

It can be concluded that in the future architecture in extreme conditions will be related to the need to rebuild the natural environment. Attempts to build artificial glaciers are already being made as an adaptation strategy towards climate change.

\section{References}

1. G. Schulze, Winter Wonderland, Superlatives and Arriving. Lois Hechenblaikner`s Photographic Tightrope Act (2012)

2. Op.cit.

3. J. Hörl, D. Schöndorfer, Die Großglockner Hochalpenstraß. Erbe und Auftrag (2015)

4. A. Frearson, [online] https://www.dezeen.com/2011/12/03/new-refuge-gervasutti-byleapfactory/(2011)

5. Funivie Monte Bianco S.p.A., [online] http://www.montebianco.com

6. H. Julen, U.Lehmann, [online] http://www.peakarchitekten.com/en/ GlacierRestaurant-Klein-Matterhorn-Zermatt/5

7. Matterhorn Zermatt Bergbahnen AG, [online] https://blog.matterhornparadise.ch/en/the-stations-for-the-3s-cableway_blog-68750

8. Herzog \& de Meuron, [online] https://www.herzogdemeuron.com/index/projects/complete-works/351-375/374-2cable-car-toggenburg.html

9. A. Frearson, [online] https://www.dezeen.com/2015/06/30/herzog-de-meuronmountain-top-restaurant-cable-car-station-wood-switzerland/ (2015)

10. N .Schwaller, [online] https://www.architonic.com/en/story/noemie-schwallerwelcome-to-vertigo/7000213 (2008)

11. B. Ritschel, T. Dauer, Hütten: Sehnsuchtsorte in den Alpen (2016)

12. T. Ulanowski, Gazeta wyborcza 30.12.2017-1.01.2018, 21 (2018) 